\title{
Early Buddhist Texts: Their Composition and Transmission
}

\author{
Mark Allon ${ }^{1}$
}

Accepted: 18 November 2021/Published online: 26 January 2022

(C) Crown 2021

\begin{abstract}
This article discusses the composition and transmission of early Buddhist texts with specific reference to sutras. After briefly summarizing the main reasons why it is likely that these oral compositions were designed to be memorized and transmitted verbatim, I will discuss the main types of changes that these texts underwent in the course of their transmission and the reasons such changes occurred, then attempt to give an account of the challenge that change, particularly intentional change, posed to the oral transmission of fixed, memorized texts.
\end{abstract}

Keywords Early Buddhist texts · Orality · Memorization · Textual change · Comparative studies

\section{Introduction}

In Style and Function: A Study of the Dominant Stylistic Features of the Prose Portions of Pāli Canonical Sutta Texts and their Mnemonic Function (Allon, 1997b, summarized in Allon, 1997a) I undertook a detailed analysis of the main stylistic features of early Buddhist prose sutra texts and, on the basis of these studies, argued that these texts were designed to be memorized and transmitted verbatim. I also argued that the communal or group recitation of texts that was common in the early Buddhist community and that was an essential part of the transmission of texts by the bhānakas, or specialist reciters, required fixed wording; as briefly summarized in a more recent article: "Group recitation requires that the wording of the text and the arrangement of the textual units within a collection be fixed; otherwise you would have complete chaos" (Allon, 2018, p. 236; cf. Allon, 1997b, p. 366).

Mark Allon

mark.allon@sydney.edu.au

1 Department of Indian Subcontinental Studies, University of Sydney, Sydney, Australia 
In my recent article "The Formation of Canons in the Early Indian Nikāyas or Schools in the Light of the New Gāndhārī Manuscript Finds" (Allon, 2018), I argued against the idea proposed by some that neighbouring monasteries of the same nikāya transmitted different versions of the same sutra and āgama, stating,

The investment of time and labour that must have gone in to memorizing and transmitting sütra and verse collections, as with any text, combined with the demands of communal recitation, would ensure that communities would have been slow to make changes to their collections since each change would involve considerable time and energy in relearning the material, besides the effort needed to arrive at a consensus to make the changes. (Allon, 2018, p. 236)

Since publishing Style and Function much of my energy has been spent studying and publishing Gandhari versions of canonical sutra texts, and a central component of these studies has involved comparing the Gandhari versions with parallels in other languages (Pali, Buddhist Sanskrit, Sanskrit, Chinese, etc.) that belong to different nikâya communities and textual lineages. ${ }^{1}$ As is immediately obvious to anyone who has read and studied parallel versions of canonical sutra texts, no two versions are identical, the differences ranging from minor to quite substantial. In fact, differences are sometimes discernible between versions transmitted by the same nikāya community. Difference within similarity is the norm, which shows that Buddhist communities were quite willing to make changes to the texts they were supposedly transmitting as fixed texts, though on the whole they were generally quite conservative. But if Buddhist communities were transmitting fixed texts, then how and when were these changes introduced, and indeed why where they changed, and how did reciter communities adapt to these changes? In my recent book The Composition and Transmission of Early Buddhist Texts with Specific Reference to Sutras (Allon, 2021) I further explore the composition and transmission of early Buddhist texts and attempt to answer these questions. I also provide a response to several recent publications that deal with the issue of the composition of early Buddhist texts. The present article condenses the main arguments of Allon, 2021, to which the reader is referred for details. ${ }^{2}$

\section{The Stylistic Features of Sutra Prose and What They Reveal About the Composition and Transmission of These Texts}

Early Buddhist sutras had two main functions. The first was to record the teachings, ideas and actions of the Buddha and members of his community of practitioners and sympathizers (monks, nuns, laymen, gods, deities, etc.), whether historic events or literary artifices, for the purpose of instructing and guiding and in order to provide models for instructing and guiding, including providing models for the defeat of

\footnotetext{
1 See, for example, Allon (2001, 2007a, 2009[2013], 2020) and Allon and Salomon (2000).

2 For an introductory discussion of what I mean by "early Buddhist texts" and "early Buddhist sutras" and of what constitutes a sutra, see Allon (2021, pp. 2-6).
} 
rivals and their views. In the process they record instances of individuals' experiences, insights, inspirations, understandings and practices, which again, may be based on a historical event or be purely literary. The second function was to inspire in order to attract converts, to motivate the converted, and to attract financial supporters, that is, these texts function as inspiration and propaganda, which includes showing the Buddha, his teaching, and his community of monastics to be superior to all others, including the gods, recording the defeat of rivals, profiling the attainments of community members, presenting instances of conversion thereby acting as models for conversion-especially of wealthy and elite individuals such as kings, merchants, prominent courtesans, and the like, those of other religious and ideological persuasions, such as ascetics and brahmans, as well as the spiritually advanced and the ordinary-, and then also illustrating the generous patronage the community received.

Early Buddhist texts, whether prose, verse or mixed prose and verse, are very much textual or literary artifices. They are not verbatim, or tape-recorder, records of the sayings and discourses of the individuals concerned nor casual descriptions of their actions or of related events. They are highly stylized, formally structured, extremely formulaic and repetitive, carefully crafted constructs, at least as we have them. And this is so at all levels. Further, the wording used to describe or depict a given event, concept, teaching, or practice is highly standardized across the corpus of such texts transmitted by a given monastic community. As such they do not reflect how a person would normally speak, preach, debate, and interact, or describe an event. ${ }^{3}$ An example that illustrates well the character of early Buddhist prose is the Buddha's description of the practice of the four brahmavihāras, or "divine abidings" (e.g. MN I 38.20-30). Whenever this practice is described in Pali suttas, it is done so by means of this formula, the repetitive usage making it a formula. ${ }^{4}$

so | mettā-sahagatena cetasā | ekam disam pharitvā | viharati | tathā dutiyam tathā tatiyam tathā catutham. I iti । uddham adho tiriyam sabbadhi sabbatthatāya I sabbāvantam lokam I mettā-sahagatena cetasā | vipulena mahaggatena appamānena averena avyāpajjhena ${ }^{5} \mid$ pharitvā $\mid$ viharati

so karun̄ā-sahagatena cetas $\bar{a}$... (as above)

so muditā-sahagatena cetas $\bar{a}$... (as above)

so upekkhä-sahagatena cetas $\bar{a}$... (as above)

The description of each brahmavihāra is identical except for a change of the word for the brahmavihära that occurs in each of the two sentences that make up the description of each brahmavihāra (the word in bold in the above text), namely, loving-kindness (mettā-), compassion (karuñā-), sympathetic joy (muditā-), and equanimity (upekkhā-). The vertical lines added into the above Pali text of the first

\footnotetext{
${ }^{3}$ For detailed study of some of the major stylistic features of Pali canonical prose sutta texts, see Allon (1997b) which can be downloaded from my Academia.edu site: https://sydney.academia.edu/MarkAllon. For the stylistic features of some Sanskrit Buddhist sutra texts and a comparison with Pali versions, see von Simson (1965).

4 The vertical dividing lines are included to facilitate analysis of the passage. They are not traditional punctuation marks.

5 The reading alternates between avyāpajjhena, abyāpajjhena, abyābajjhena, abyāpajjena.
} 
brahmavihära demarcate the building blocks, the syntactically discrete units used to construct the description of the practice. ${ }^{6}$ Following general English syntax, the units are: he dwells (so ... viharati) I having pervaded one direction (ekam disam pharitva $\bar{a}$ | with thought of loving-kindness (mettā-sahagatena cetas $\bar{a})$ I so (also) the second (direction), so the third, so the fourth (tathā dutiyam tathā tatiyam tathā catutham). I Thus he dwells (iti ... viharati) I having pervaded the entire world (sabbāvantam lokam ... pharitvā) I above, below, all around, everywhere, entirely (uddham adho tiriyam sabbadhi sabbatthatāya) I with thought of loving-kindness (mettā-sahagatena cetasā) I abundant, great, immeasurable, without hate, without ill-will (vipulena mahaggatena appamānena averena avyāpajjhena). I

The first sentence gives a brief description of pervading each of the four directions with the brahmavihāra concerned, while the second uses the same basic sentence (so/iti ... mettā-sahagatena cetasā pharitvā viharati) to express the thoroughness of the directionality of the practice: "above, below, all around, everywhere, entirely, the entire world" (uddham adho tiriyam sabbadhi sabbatthatāya I sabbāvantam lokam), and to list more specific qualities of the brahmavihāra: "abundant, great, immeasurable, without hate, without ill-will" (vipulena mahaggatena appamānena averena avyāpajjhena).

The importance of repetition to the authors of these texts is evident in this brahmavihāra formula. Had textual economy been important, they could have just as effectively listed all four brahmavihäras together in a single passage and dispensed with mentioning each direction individually, for example, *so ekamekam mettā-karun̄ā-muditā-upekkhā-sahagatena cetas $\bar{a}$ catuddis $\bar{a}$ pharitvā viharati ...., "He pervades the four directions in due order with thought of loving-kindness, compassion, sympathetic joy and/or equanimity ...".

The highly structured, carefully crafted nature of the text as illustrated by this example, as with all canonical prose, is further evident at the most granular level, that is, in the choice of words and the building up of text. For example, a characteristic feature of canonical prose are strings of grammatically parallel units, such as nouns, adjectives, verbs and adverbs, that express the same or similar general idea, with each subsequent unit nuancing or expanding the meaning of the preceding ones, presenting further qualities of the thing described, or presenting a similar category of item. So the Buddha does not simply instruct someone with a Dhamma talk (dhammiya kathāya sandassesi), but he instructs, urges, rouses, and encourages them with such a talk (dhammiyā kathāya sandassesi samādapesi samuttejesi sampahamsesi, e.g. MN I 146.27-28); that is, his act of teaching is expressed through four semi-synonymous verbs rather than one. Further, the component units of these structures or strings are normally arranged according to a waxing number of syllables, that is, the first unit has fewer syllables than the last (or at least their count does not decrease); for example, the syllable pattern of the above

\footnotetext{
${ }^{6}$ There are different ways of dividing the text, including into different subdivisions, for example, tath $\bar{a}$ dutiyam tathā tatiyam tathā catuttham could be further analysed as I tathā dutiyam $\mid$ tatha tatiyam $\mid$ tatha catuttham I, but that adopted here will do for our purposes.
} 
four verbs sandassesi samādapesi samuttejesi sampahamsesi is $4+5+5+5$. $^{7}$ It is also not uncommon in these string structures for the initial members to be single words and the latter members to consist of compounds in the case of strings of adjectives and nouns, or of verb-object phrases in the case of strings of verbs, and so on, as a means of generating the waxing of syllables. Examples are unnādino uccāsaddamahāsaddā, "exclaiming loudly, with a loud noise, with a great noise", discussed below where the second member is a compound, and majjati mucchati pamādam apajjati $(3+3+7$ syll.), "he is intoxicated, infatuated, and careless" (DN III 42.28), where the first two members are simple verbs while the last (pamādam äpajjati) is a verb-object phrase. The members of these strings also regularly exhibit sound and metrical similarities or repetitions. For example, in majjati mucchati pamādam $\overline{a p a j j a t i}$ there is repetition of labial sounds $m$ and $p$ and of $m \bar{a}$ : majjati mucchati pamādam äpajjati, and repetition of the palatal consonant cluster in combination with the verbal termination: majjati mucchati pamādam äpajjati. The first two verbs

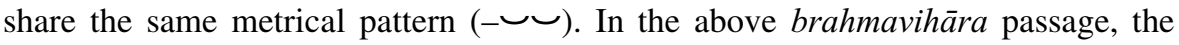
string of five adjectives vipulena mahaggatena appamānena averena avyāpajjhena qualifying cetas $\bar{a}$ can be understood to consist of two groups with a $4+5+5,4+5$ waxing syllable pattern, the first group of three referring to quantity and expanse (abundant, great, immeasurable), and the following group of two members referring to positive psychological qualities (without hate, without ill-will). Sound similarities are evident in the final three words which help to bind the two groups together. Similarly, the five adverbs or adverbial expressions uddham adho tiriyam sabbadhi sabbatthatāya have a $2+2+3+3+5$ waxing syllable pattern, which could in fact be understood to consist of two groups $2+2+3,3+5$ based on general meaning and the last two words being based on sabba-, "all", which in turn connects this string with the following noun phrase sabbāvantam lokam. Finally, the four brahmavihäras of mettā ... karun̄a ... muditā ... upekkhā have a $2+3+3+3$ waxing syllable pattern. ${ }^{8}$

The tight composition and in some cases "artificiality" of such string structures is further illustrated by instances of words within them only being found in that particular string. An example is tam tad eva te kumārakā vā kumārikā vā kațthena vā kațhalena vā sañchindeyyum sambhañjeyyum sampalibhañjeyyum, "those boys and girls would break off that [crab's claw], smash it, crack it with sticks and stones" (MN I 234.14-16; SN I 123.25-27). ${ }^{9}$ Here the word kathala-, "stone", only occurs in sutta prose in this pair kațtha- kațala-, "stick [or] stone", ${ }^{10}$ while the finite forms of the final two verbs sam- $\sqrt{b} h a \tilde{n} j$ and sampali- $\sqrt{b} h a \tilde{n} j$ in the string sañchindeyyum sambhañjeyyum sampalibhañjeyyum, "break off, smash, crack", are only found in canonical prose in this simile of the crab, which itself only occurs twice in the Pali canon; of course, it goes without saying that the three verbs only occur together in

\footnotetext{
7 The phenomenon of arranging such material according to syllable length is well known in many fields, but for the purpose of my Cambridge PhD thesis submitted in September 1994 and subsequently published as Allon (1997b) (see p. 191), I coined the phrase Waxing Syllable Principle (WSP).

${ }^{8}$ For a far more comprehensive study of the stylistic features discussed in this section, see Allon (1997b, pp. 191-272, 364-367).

9 SN reads kumārikāyo vā katțhena vā kațalāya.

${ }^{10}$ E.g. MN I 128.23; see CPD s.v. kațalä.
} 
this simile. In other words, the two verbs sambhañjeyyum sampalibhañjeyyum were created for this specific context to be combined with the first verb sam $-\sqrt{c} h i n d$, which does occur in other contexts, to create a string of three semi-synonymous verbs that waxed in syllables $(4+4+5)$ and shared sound and metrical similarities or repetitions (the first two verbs have the same metrical pattern of four long syllables - - - ). So also, the authors of this passage undoubtedly chose the rare word for stone kathala rather than a more common one like silā or pāsāna because of its sound similarities with kattha, "stick", and because they formed a nice waxing syllable pair, in the case of katthena vā kathalena $v \bar{a}$ of 3+4 syllables, the pair also forming a sound play with the word for crab, kakkataka and perhaps even the word for claw, ala. ${ }^{11}$ As I noted of these structures in my detailed study of them (Allon, 1997b, p. 251):

The proliferation of similar word elements and units of meaning and the ordering of the member elements of such sequences according to the Waxing Syllable Principle, which thus produces an overall crescendo effect, tends to give a rhythm and homogeneity to this material. This rhythm and homogeneity is then greatly enhanced when, as is frequently the case, the member elements also share sound and metrical similarities. The presence of rhythmical patterns in prose, and especially in long prose texts, must have been extremely important to those who performed or recited this material, and may be functionally parallel to the rhythm produced in verse by metre.

A passage that further illustrates the building block approach to constructing prose text is the following (DN III 40.16-20), once again the vertical lines demarcating the building blocks: ${ }^{12}$

evam vutte | te paribbājakā | unnādino uccāsadda-mahāsaddā | ahesuṃ: | acchariyam vata bho I abbhutam vata bho I samaṇassa Gotamassa I mahiddhikatā mahānubhāvatā | yatra hi nāma | saka-vādam thapessati | para-vādena pavāressat̄̄ $t i$

When (the Buddha) spoke thus, those ascetics exclaimed loudly, with a loud noise, with a great noise: "Wonderful, sir! Marvellous, sir! is the greatness and power of the monk Gotama since he withholds his own theories and invites the theories of others!"

What is most evident in this passage is the not uncommon tendency to create and use building blocks that consist of pairs of words or related textual units. The first is the locative absolute evam vutte, literally "when it was said thus". The following subject of the sentence is not the simple noun paribbajjaka, "the ascetics", but te paribbājakā, "those ascetics", a pronoun plus noun. This is then qualified by two predicative attributes, the second a compound, unnādino uccāsadda-mahāsaddā, "exclaiming loudly, with a loud noise, with a great noise", which have a 4+8 waxing syllable pattern and exhibit sound repetitions, each beginning in two heavy syllables. The ascetics' exclamation begins with two parallel expressions

\footnotetext{
${ }^{11}$ Further instances of words only occurring in such strings are given by von Hinüber (1994), e.g. pp. 17$22,24$.

12 This passage was also analysed in Allon (1997b, pp. 205, 296-297).
} 
acchariyam vata bho I abbhutam vata bho, "Wonderful, sir! Marvellous, sir!", which have the same syllable count if the epenthetic vowel is not scanned in acchariyam, besides sharing sound repetitions and repetition of wording. The reference to the Buddha is not merely his name Gotama but samanassa Gotamassa, "of the ascetic Gotama", parallel to te paribbājaka, "those ascetics". The subject of the clause, mahiddhikatā mahānubhāvatā, "greatness (and) power", consists of two synonymous abstract nouns in -tā beginning with $m a h \bar{a}-$-, "great", that have a 5+6 waxing syllable pattern and share the same metrical pattern in the first three syllables. Finally, the ascetics' exclamation ends in two parallel units each consisting of verb and "object" saka-vādam thapessati | para-vādena pavāressati, "he withholds his own theories (and) invites the theories of others", that has an $8+10$ waxing syllable pattern, with each unit having the same metrical pattern in the first five syllables.

Nothing in canonical sutra prose is casual. It is as highly structured as verse, if not more so. In fact, apart from many of the component elements of these string structures exhibiting metrical similarities, some canonical prose is metrical, ${ }^{13}$ the metre commonly being referred to as vedha. The most well-known example of this is the so-called iti pi so formula studied, in particular, by Bechert $(1988,1991) \cdot{ }^{14}$ As with the string structures discussed above, these loose vedha-like passages may also have provided a rhythm to chanting the material (Allon, 1997b, pp. 248-249).

The above features are in various ways all forms of repetition. But the authors of early Buddhist prose pursued other forms of repetition on a truly grand scale. For example, in my detailed analysis of one sutta in the Digha-nikāya (Allon, 1997b, pp. 273-363), I identified several types of quantifiable repetition (Verbatim Repetition, Repetition with Minor Modifications, etc.) and showed, for example, that $30 \%$ of this sutta consisted of various passages repeated verbatim two, three or four times and that another $35 \%$ of this sutta involved repetition with minor modifications at a primary level. An example of Repetition with Minor Modifications is the above brahmavihära passage in which an identical description is repeated four times with one word, the word for the brahmavihära, substituted in each. Astonishingly, in total almost $87 \%$ of the sutta studied involved quantifiable repetition of one kind or another at a primary level (repetition is also quantifiable within these primary repetitive passages). Further, although $13 \%$ of the sutta did not occur again within this sutta, much of that wording does occur in other suttas in the Pali canon.

Another dominant stylistic characteristic of early Buddhist sutra prose is the use of formulas, that is, the wording used to depict a given concept, action, or event is highly standardized and predictable. The description of the four brahmavihära discussed above and the iti-sīla-samādhi-paññäliti-síla-samādhi-prajñā formula discussed below are examples of such formulas. ${ }^{15}$

\footnotetext{
$\overline{13}$ Gamage (2012, pp. 143-144) raises the possibility that the reference to suttanta-vatta as one of the three kinds of vatta (which he translates as "cadence") listed in Sp VI 1202.12-13 (dhamme pana suttantavattạn nāma atthi jātakavattam nāma atthi gāthāvattam nāma atthi) and defined in the Pācityādiyojanā $(\mathrm{Be} 452)$ as suttantavattan ti suttantassa uccāranam vattam, may refer to ways of reciting prose, though the tradition does not elaborate on this.

${ }^{14}$ For examples of loose vedha-like passages, see Allon (1997b, pp. 246-249).

${ }^{15}$ For the most detailed analysis of a whole class of formula, namely, formulas used to depict someone approaching someone else, see Allon (1997b, pp. 9-190).
} 
As noted at the start of this discussion, the stylistic features of canonical Buddhist prose sutra texts, such as formulas, the proliferation of similar word elements with members chosen to maximize sound and metrical similarities, large scale repetition, the use of metrical prose, and the building block approach to constructing text indicate that these texts were designed to facilitate the memorization and faithful transmission of this material as fixed text. These are not characteristics one would expect of improvised composition. Although in Style and Function (Allon, 1997b) I primarily explored the function of these features as aids to the composition and transmission of the literature, they undoubtedly have other dimensions of equal importance. For example, these features have aesthetic and poetical dimensions, which may have functioned to emphasise aspects of the ideas, practices, personalities, and so on, being described, and contributed to the overall attractiveness and emotional force of the material, thereby heightening the impact it had on the audience. Such features may also have been valued for the psychological impact they had on those who memorized, contemplated, and recited these texts, including the attainment of meditative states. ${ }^{16}$

\section{References Within Canonical Texts to Texts Being Memorized and Recited Communally}

Apart from the fabric of the texts themselves, that is, the very way in which they have been constructed, further evidence for texts being memorized and transmitted verbatim comes from numerous references within early Buddhist texts themselves that describe the recitation and learning of texts, where it is hard to imagine that fixed texts are not what is meant. These have been discussed at length by several authors ${ }^{17}$ and I will not rehearse them. Suffice it here to mention a few examples to illustrate the point.

In a passage found in the Pali Udāna and Mahāvagga of the Vinaya the Buddha asks the monk Sona, who had been a monk for only a year (ekavasso aham), to expound the Dhamma (patibhātu tam bhikkhu dhammo bhāsitum), ${ }^{18}$ which the Udāna commentary glosses with yathāsutam yathāpariyattạn dhammam bhañāin ti attho, "the meaning is "recite the Dhamma as (you) have heard and learnt it"" (Ud-a 312.13-16). In response Sona recites the sixteen suttas of the Atthakavagga, which is generally considered to belong to the oldest strata of the canon and now forms a part of the Suttanipāta: solasa ațthakavaggikāni sabbān' eva sarena abhaṇi, "he

\footnotetext{
16 For some mention of other possible functions of these features and references to those who have suggested them, see Allon (1997b, pp. 162-166, 249-252, 357-367). For recent studies of the literary dimensions of early Buddhist texts, see Shulman (2012[2013], 2017).

17 The most comprehensive discussion of such passages is provided by Anālayo (2011) "Introduction" (pp. 1-22) and "Conclusion" (pp. 855-891). See also Allon (1997b, pp. 1-2), Anālayo (2014a, 2015), Collins (1992), Cousins (1983), Drewes (2015), Norman (2006, pp. 53-74) and Wynne (2004). Lamotte (1985, pp. 6-9) discusses interesting examples of monks who have memorized the wording, the text, but have not learnt the meaning.

${ }^{18}$ Ud 59.21-22; Vin I 196.34-35. The reading is that of the Vin; the Ud has the w.r. patibhātu bhikkhūnam dhammam bhāsitum as noted by Ud-a Ee 312 n. 1.
} 
recited all sixteen Atthakavagga (suttas) with intoned voice". ${ }^{19}$ The Udāna commentary confirms the identification of the text involved: solasa atthakavaggikān̄ ti aț̣hakavaggabhūtāni kāmasuttādīni soḷasa suttāni, " "sixteen belonging to the Atthakavagga' are the sixteen suttas that make up the Atthakavagga beginning with the Kāma-sutta" (Ud-a 312.16-17). The Buddha praises Sona with the words sādhu sādhu bhikkhu. suggahitāni (te) bhikkhu solasa ațhakavaggikāni sumanasikatāni sūpadhāritāni, ${ }^{20}$ "Well done, well done, monk! Monk, the sixteen (suttas) belonging to the Atthakavagga have been well grasped by you, well attended to, well reflected upon". This account suggests that the initial training for Sona and probably also for other new monastics included memorizing and learning to recite texts. But there is nothing surprising about this given the oral context. Young brahmans, and probably also other religious ascetics, had been doing this for many centuries prior to the birth of the Buddha. There are also several suttas that refer to nuns, laymen and laywomen reciting or having memorized the Atthakavagga or Pārāyanavagga or sections of these collections, besides other texts. ${ }^{21}$

Again, two suttas in the Anguttara-nikāya $a^{22}$ list things that result in the decline and disappearance of the good Dhamma (saddhamma) and their opposites that conduce to its continuance and non-disappearance. In the second category, the first is that the monks learn the suttantas that have been well grasped (suggahitam suttantam pariyāpunanti) and whose words and phrases are well laid down (sunikkhittehi padavyañjanehi), since the latter results in the meaning being well interpreted (attho pi sunnayo hoti), a description that brings to mind the stylistic features discussed above. The third is that the monks are learned (bahussutā), have mastered the tradition (āgatāgamā), are expert in the Dhamma (dhammadharā), Vinaya (vinayadharā), and outlines (mātikādharā) and teach the suttantas to others so that after their death the suttantas will not be lost but will remain (te sakkaccam suttantam param vācenti, tesam accayena na ca chinnamūlako suttanto hoti sappatisarano).

Finally, as is well known, the institution of learning and regularly reciting the monastic rules, the Pātimokkha/Prätimokșa, seems to have begun relatively early in the life of the Buddhist community, being depicted as having been initiated by the Buddha himself (e.g. Vin I 102-104). And, indeed, there are many accounts of reciting and mastering the Pätimokkha, with mastery of it, for example, being a requisite for ordaining and instructing others, being considered one who knows the Vinaya (vinayadhara), and so on. ${ }^{23}$

\footnotetext{
19 Ud 59.23; Vin I 196.36 reads sabbān' eva ațthakavaggikāni sarena abhāsi.

${ }^{20}$ Ud 59.25-26; Vin I 196.38-197.1. Ud Be suggahitāni te, Vin Be Ce Ee suggahitāni kho te; Vin Be Ce Ee omit solasa.

21 See Allon (2021, Chapter 3), for these examples.

22 AN 4.160 at II 147-149; cf. 5.155-156 at III 177-180.

${ }^{23}$ For more details, see Allon (2021, Chapter 3).
} 


\section{The Formation of Sutra and Verse Collections, and the samgitikäras and bhänakas}

The tight control over textual production and organization aimed at facilitating faithful transmission of that textual material is further witnessed by the way in which similar textual units such as sutras and verses were brought together to form larger collections of such units and even composed for a particular context, namely, nikāyas/ägamas and individual verse collections such as the Dhammapadal Dharmapadas, Theragāthā and Therīgāthā. This was done on the basis of genre, size, purpose, a numerical principle, subject matter, and so on. The textual units within these larger collections were further organized into more manageable subdivisions, such as vagga/vargas, samyutta/samyuktas, and nipātas, and then, in the case of sutra collections, into the most basic grouping of the vagga/varga that consists ideally of ten sutras, the number ten perhaps being influenced by the fact that we have ten fingers. The larger collection was also sometimes divided into bhānavāras, or recitation sections, where a bhānavāra is said to consist of 8000 akșaras or syllables. ${ }^{24}$ Yet another system of organization occasionally used for large collections was to arrange the member sutras into groups of 50, or pañ $\tilde{a} s a k a s$, a system used, for example, to group the 152 suttas of the Majjhima-nikāya into three pañ̃āsakas. A further set of organizational principles was then used to guide the inclusion and arrangement of textual units within these secondary and tertiary divisions. This included genre, size, whether verse was included and how many verses were involved, subject matter, a numerical feature, a connection based on a key word or words, or key concepts, the manner of treating a topic, including its treatment in brief and in expanded form, the individuals involved, such as who delivered the discourse or spoke the verses or the one to whom they were addressed, the location of events depicted, and figures of speech such as a simile or metaphor, to mention only the main ones. ${ }^{25}$ An organizational principle that is particularly common, but little studied, is the tendency to form pairs of textual units or occasionally longer runs, whether sutras and verses, within a division such as the vagga/varga based on a key word, the subject matter, a specific individual or class of person, a numerical principle, a figure of speech, and so on. ${ }^{26}$

An interesting feature of some sections of canonical collections is the seeming "artificiality" of the sutras and verses that make up a vagga/varga or similar division. This is particularly evident in the Samyutta-nikāya/Samyuktāgamas (SN/ $\mathrm{S} \bar{A}$ ) and Anguttara-nikāya/Ekottarikāgamas (AN/EĀ). By way of example, in the Nidanna-samyutta of the Pali SN, the first vagga of this samyutta, the Buddha-vagga, consists of ten suttas (SN 12.1-10 at II 1-11) which all depict the Buddha living in Sāvatthi and addressing the monks on the topic of paticcasamuppāda, dependent arising. In the first sutta (12.1) the Buddha tells the monks that he will teach (desessāmi) them pațiccasamuppāda and he presents a basic account of pațiccasamuppāda, while in the second sutta (12.2) he tells them that he will teach and

\footnotetext{
$\overline{24}$ bhānavāro mato eko, svațthakkharasahassako (Sv-nț Be I 81.9-12).

25 For more detailed discussion of these organizational principles, see Allon (2021, Chapter 4).

26 The most detailed studies to date are Allon (2001, pp. 18-22; 2021, pp. 31-35).
} 
analyse (desessāmi vibhajissāmi) paticcasamuppāda and does so by defining each member of the paticcasamuppāda set. These suttas form a pair, with the second being longer than the first. The bare bones account of paticcasamuppāda of the first sutta is very short, seemingly too short for a formal discourse. One would expect that the brief account would normally have been followed by the more detailed analysis or have formed part of a more complex discourse, as recorded elsewhere in the canon. It seems that the first sutta of this vagga, which is also the first sutta of the samyutta, was created to present the most basic account of paticcasamuppāda, while the second was created to provide definitions of the individual terms. The third sutta (12.3) consists of a brief account of paticcasamuppāda in terms of wrong and right way (micchāpațipadañ ca ... sammāpațipadañ $c a$ ), which appears to be a nuancing of the understanding presented in the first two suttas. In the remaining seven suttas of the vagga the Buddha gives an account of the realization of pațiccasamuppāda by the seven buddhas, beginning with the past buddha Vipassī and ending with himself. Each account is identical except for the change of the name of the buddha. It is hard to imagine the scenario presented here in which a teacher, in this case the Buddha, gives separate discourses on individual buddha's on different occasions. A more likely scenario is that such a teacher would give an account of his own realization of paticcasamuppāda, as we find presented for the Buddha elsewhere in the canon, possibly then followed by a brief statement that the same occurred for the six past buddhas, or more likely, that the Buddha's account of his own realization was applied to the past buddhas by those who composed these texts to form six additional suttas.

An even more extreme example in the Nidāna-samyutta is the Samanabrāhmanavagga (SN 12.71-81 at II 129-130), which consist of eleven virtually identical suttas in each of which the Buddha states that there are some monks and brahmans who do not understand one of the eleven links of paticcasamuppāda (old age and death, etc.) and who therefore have not realized the purpose of being an ascetic or brahman, while there are some monks and brahmans who do understand them. Once again, it is hard to imagine that a teacher would give eleven separate discourses each dealing with only one link. It is far more likely that those responsible for the composition of this material divided what was originally a single discourse to form eleven suttas and thus an independent vagga in the case of the Samanabrāhmanavagga, or the last seven suttas of a vagga in the case of the Buddha-vagga. ${ }^{27}$

The large amount of repetitive material and the forms of repetition that resulted from multiplying parallel textual units (sutras in this case) that were produced by applying the same frame, the same formulaic passage, to individual items that would more naturally occur together within one sutra, may itself have been a reason for doing so. This repetition is very much in keeping with the way in which repetition is built into the very design of early Buddhist texts from the smallest building blocks to the overall structure of the larger unique sutras such as those of the DN/DĀs and MN/MĀs, and then across the textual units within a collection or collections by means of the standardization of the wording used to depict a given

\footnotetext{
27 For this phenomenon of generating "artificial" or pseudo-suttas (as they refer to them) in the AN/EĀs, see Kuan and Bucknell (2019).
} 
concept, action or event, namely through the use of formulas, through the use of standardized sutras structures, and so on. Memorizing and reciting the eleven suttas of the Samanabrāhmana-vagga discussed above in which identical wording concerning whether some monks and brahmans do or do not have understanding is applied to eleven of the twelve links of paticcasamuppāda would certainly have ensured accurate transmission of that material. But in addition to this, and perhaps even more importantly, it would have acted as an important tool for mental training, for the development of concentration and attention to fine detail, and as a meditative exercise. One had to be keenly alert to the wording, particularly the moments when key words were to be substituted for the next item in the sequence. ${ }^{28}$ There is also something in this of the atomization of truth statements in which each and every element or dhamma of a teaching or doctrinal set is isolated and emphasised, being ideal for meditative contemplation.

It is evident that canonical collections are not merely the result of the arranging of pre-existing sutras or verses according to certain organizational principles. Sutras and verses were created for a particular context, to present the teachings and practices in a particular order or manner, to develop a particular theme, to develop a particular vision of the Buddha, and so on.

It is highly likely that a teacher like the Buddha, who is said to have preached for 45 years, would speak on the same topic many times throughout his teaching career, varying his discourse to suit the occasion, the content and delivery changing as his experience and understanding of his audience developed, and no doubt as his own understanding matured. This being the case, the phenomenon of sutras and other textual units being arranged in pairs indicates that an enormous amount of culling and modification of discourses must have occurred when these collections were created, a process that seems to have gone hand-in-hand with the creation of textual units just discussed.

Finally, the arrangement of textual units within collections and the faithful transmission of these collections is controlled by means of the para-textual mechanism of the uddanas, or mnemonic verses, that key off the members of the group of textual units by means of a keyword of the textual unit being referenced or a word encapsulating its main topic. These function to ensure the membership of the collection (inclusion) and the correct ordering of the members and would have been memorized by the bhanakas and those who wished to memorize the text or a section of it. ${ }^{29}$

The way in which collections of textual units were created, with a sophisticated set of principles guiding the selection of the textual units for inclusion and their arrangement within the collection and its subdivisions, further illustrates the degree of control that was exercised over the production and organization of early Buddhist texts, at least as we have them. The creation of textual units such as sutras which involved multiple and complex decisions regarding language, genre, structure, length, diction, style, standardization, and the creation of collections of such units that clearly involved selecting, culling, and even proliferating textual units, must

\footnotetext{
${ }^{28}$ See Gethin (2007, esp. p. 382) (pp. 382-383 he also explores repetition as a common religious phenomenon).

${ }^{29}$ See Allon (2021, pp. 41-42), for further discussion.
} 
have been an enormous group undertaking that involved considerable investment of time and effort, as would have been the process of getting the results ratified by the community, to say nothing of its subsequent transmission. Very little of the texts that have survived indicate that they are the result of spontaneous creativity, of composition in performance, an understanding that is supported by what we know of the history of early Buddhist communities.

Alongside references in the sutras and the Vinayas to texts being memorized and recited, we find many references to those who are expert or learned in certain classes of text or forms of transmission (several of which were mentioned in passages discussed above), including suttantika, "who knows the suttantas", āgatāgama, "has mastered the tradition", dhammadhara, "expert in the Dhamma", vinayadhara, "expert in the Vinaya", mātikādhara, "expert in the outlines", dhammakathika, "a Dhamma preacher", and bhānaka, "reciter". 30 However, we have very little understanding of the formation of early Buddhist texts, of what was composed during the Buddha's lifetime, of the characteristics of those initial compositions, of how the first samgit $i$ worked and what texts were recited on that occasion. We have no idea of the relationship between the texts and collections we have and those early works, nor how the bhānaka system worked, the extent to which the bhānakas modified or even formed the material they transmitted, and the impact subsequent samgitis and redaction events had on the material transmitted.

Although individuals may have mastered particular collections and thereby been known as bhạnakas, what we do know of the institution of the bhānakas, including the impact they had on the material they transmitted and the different views different bhạnaka communities are said to have had on certain topics, indicates that they must have learnt and recited texts communally, which by default involves fixed texts, because as stated at the beginning, group recitation requires that the wording of the text and the arrangement of the textual units within a collection be fixed. Besides, without a continuous tradition of the communal memorization and validation of texts, we would not have the material that we do that exhibits the peculiar stylistic features and systems of organization I have described, that are preserved in such ancient languages, with parallel versions exhibiting such similarities.

\section{The Main Differences Between Parallel Versions of Early Buddhist Texts and Accounting for These Differences}

When we compare parallel versions of sutras and verses that have been transmitted by different communities at different times and locations, they exhibit a great range of differences within an overall similarity, something that is sometimes observable even in the texts transmitted by the same nikāya, such as the Theravāda.

The main differences encountered between parallel versions of early Buddhist texts preserved in Pali, Gandhari, or other Prakrit, in Buddhist Hybrid Sanskrit,

Sanskrit, Chinese and/or Tibetan are, apart from language and language related phenomena, the following:

\footnotetext{
$\overline{30}$ See Allon (2021, pp. 43-44), for detailed discussion of these references.
} 
- whole episodes or descriptions of events, practices, teachings, and so on, found in one version are missing in one or more of the parallels;

- differences in the sequence of events and order in which teachings are given;

- differences in the arrangement of information within the description of an event, concept or practice;

- differences in the information given within the description of an event, concept or practice;

- different order of items in a list and differences in the number of items listed;

- differences in the names of people and places in the description of what is essentially the same event;

- differences in the wording used to portray a given event, concept or practice, including the use of different synonyms, differences in word order, and differences in the complexity of descriptions;

- differences in the use of markers such as indeclinables and vocatives of address;

- differences in grammar, e.g. verbal tense, grammatical number, etc.

And then, of course, we find major differences in the ways in which the textual units of sutras and verses were allocated to and arranged within collections of such units, namely, within nikāyas/āgamas and pitakas. The above list is by no means exhaustive.

Some of the factors that must have contributed to such changes occurring include:

- change of language;

- the bhānaka traditions;

- the authority of the teacher and his/her specialization;

- geographical isolation or separation;

- lack of centralized authority, which combined with geographical isolation would have made it difficult to maintain standard versions;

- the formation of separate nikāyas: this must have greatly multiplied the possibility of diversity in the texts transmitted, with each school maintaining, rearranging, altering, and supplementing its own version of canonical texts;

- the dynamic attitude towards what constitutes buddhavacana, the authoritative word of the Buddha;

- an emphasis on meaning rather than wording (contra the Brahmanical tradition);

- the background and mnemotechnical skills of members of the Buddhist community and the age at which they became monastics;

- the possibility that communities belonging to different nikāyas and different textual lineages influenced each other's texts; 
- the possibility that an oral performance altered for a given purpose and to suit a particular audience or a sermon based on a text influenced (altered or replaced) the communally transmitted version;

- the impact of writing and manuscript transmission, including errors and changes resulting from the limitation of script.

Once again, this list is not exhaustive. It is also quite difficult to identify which factor or combination of factors was responsible for a given observable difference.

Now the changes that texts underwent may have been intentional or unintentional, both being possible in the context of purely oral transmission and transmission involving manuscripts. By intentional I mean that the reciters or those who transmitted the text were consciously aware that they were modifying it, resulting in effort being needed to adopt and learn the modified text. Unintentional change is the opposite, occurring when the reciters were not aware that their recitation of the text differed from their previous recitation of it.

In a purely oral context, unintentional changes may result from the limitations of memory and the way memory works ${ }^{31}$ and the social background and mnemotechnical skills of members of the Buddhist community. ${ }^{32}$ Examples of unintentional changes are of a word being replaced by a similarly sounding word; words or phrases being accidentally omitted; words or phrases triggering the inclusion of a stock phrase or description found associated with that word or phrase in other texts transmitted by the community; changes in the order of items being listed or in the order of verses due to lack of adequate guides to maintaining a particular order; differences in the names of people and places; commentarial glosses being included in the root text. However, the differences encountered between parallel versions of texts cannot be accounted for by unintentional causes and "errors", if they can be called that, in oral transmission alone. It is clear that many changes were intentionally produced, which means that although Buddhists communities memorized texts and attempted to transmit fixed texts, communally reciting them, they were quite willing to change the texts they were transmitting. ${ }^{33}$ Besides, changes that arose through unintentional means must have been accepted by the reciter communities for them to have become standard as we encounter them to be, which involved intention.

A good example of relatively significant changes to the wording of a text are the last words of the Buddha spoken before his death along with the sutra narrator's words that frame them. This passage forms a part of the Mahāparinibbāna-suttal Mahāparinirvāna-sütras preserved in Pali, Sanskrit, Chinese and Tibetan belonging

\footnotetext{
31 See Anālayo (2009).

32 Allon (1997b, p. 366) and Anālayo (2009, pp. 6-7, 2011, pp. 855, 868-871) (cf. 2015, pp. 90-91) with references given there.

33 McGovern (2019, esp. pp. 467-468) argues that such differences are better explained if we dispense with the idea that early Buddhists texts were transmitting as fixed, memorized texts, the differences rather being due to variation in the text produced in improvised performance. I will return to McGovern's arguments below.
} 
to different schools. It suffices here to present the Pali version of the Theravādins ${ }^{34}$ and the Sanskrit version of the Sarvāstivādins, ${ }^{35}$ the differences highlighted in bold.

Pali

\section{Sanskrit}

atha kho bhagavā bhikkhū āmantesi:

handa dāni bhikkhave āmantayāmi vo,

vayadhammā saìkhārā appamādena

sampāiethā ti.

ayam tathāgatassa pacchimā vācā
[42.8] api tu karaṇīyam etat tathāgatena yathāpi tat paścimām janatām anukampamānah.

[42.9] atha bhagav(ān svakāyād uttarāsaingam ekān) te vivrtya bhikșūn ämantrayate:

[42.10] avalokayata bhikṣavas tathāgatasya kāyam. vyavalokayata bhikṣavas tathāgatasya kāyam. tat kasmād dhetoḥ. durlabhadarśanā y(asmāt tathāgatā) arhantah samyaksambuddhās tadyathodumbare puspam. [42.11] anga bhikṣavas tūṣnīn bhavata vyayadharmāh sarvasamskārāḥ.

[42.12] iyam tatra tathāgatasya paścimā (vācā). [The Bhagavat said:]

Then the Bhagavat addressed the monks: [42.8] "But this, however, is to be done by the Tathāgata since he has compassion on later generations."

[42.9] Then the Bhagavat, turning aside the upper robe from his own body, addressed the monks: [42.10] "Monks, gaze upon the body of the Tathāgata. Monks, gaze closely upon the body of the Tathāgata. What is the reason for this? It is because the sight of Tathāgatas, Arhats,

Completely Awakened Ones is as rare as a flower on a fig tree. [42.11] Monks, please be silent. It is the nature of all formations to disappear."

[42.12] This was, then, the last speech of the Tathāgata.

The Sanskrit version is much expanded compared to the Pali, as indicated by the amount of text in bold. In the Pali, the Buddha's speech consists of a short statement made up of nine words. This is framed by a statement by the narrator introducing the Buddha's speech and a concluding statement that these were his last words. In the Sanskrit, the Buddha's speech consists of 25 words and although the narrator's framing is similar to the Pali, it has nonetheless also been expanded. The expanded wording in the Sanskrit centres on the Buddha exposing his 80-year-old body to the monks at the time of his death, a gesture missing in the Pali, that graphically illustrates his statement that all formations are subject to change and, by extension, therefore impermanent. The Chinese versions, including that found in the Dharmaguptaka Dīrghāgama, are generally yet more elaborate than the Sanskrit. ${ }^{36}$ However, the Pali is not simpler on all accounts. Having told the monks that all

\footnotetext{
34 DN II 155.31-156.3; SN I 157.34-158.2. The reading of the Be and Ce of the SN version is the same as for DN, but Ee (SN I 158.1-2) reads appamādena sampādetha vayadhammā saìkhārā ti, for which see Anālayo (2014b, p. 9 n. 30).

35 MPS $\S$ 42.8-12. Waldschmidt's (1950-1951) edition of the MPS is based on Central Asian manuscripts. Allon (1987) provides an English translation, Weber (1999) a German one.

36 Waldschmidt (1939, pp. 56-63) translates into German and compares all versions. Anālayo (2014b) provides an English translation of the Chinese Dïrghāgama version and comparative study (pp. 1-8).
} 
formations are subject to change (vayadhammā sainkhārā), the Buddha exhorts them to strive with diligence (appamādena sampādetha), which is missing in the Sanskrit. It is possible that the inclusion of the passage describing the Buddha exposing his old body to illustrate the impermanent nature of things was included by the reciters of the Sanskrit version, or even an earlier Prakrit version in this lineage, to emphasise the humanness of the Buddha in the face of an increasing tendency to deify him. Alternatively, as proposed by Waldschmidt (1939, pp. 62-63) and furthered by von Hinüber (2019, pp. 251-252), it is a possibility that the Theravādins deliberately omitted mentioning the Buddha exposing his body in their Pali version because it detracted from their vision of the Buddha (cf. Anālayo, 2014 b, pp. 6-7). Both interpretations (inclusion or omission) involve intentional change and both may represent examples of changing a text for ideological reasons.

Alongside changes to the wording, particularly expansion of the wording, the comparison of parallel versions often reveals differences, sometimes significant differences, in the very structure of the text itself, in the course of events, and in the way in which the plot is developed. A good example of the latter, the development of plot, is the introductory narrative portion of the Sāmaññaphala-suttal Śrāmanyaphala-sūtra, a sutra that is most commonly associated with the Dighanikāya/Dïrghāgamas (DN/DĀ). There are multiple versions of this text preserved in Pali, Gandhari, Sanskrit, and in Tibetan and Chinese translation, belonging to different schools and textual lineages, the witnesses of which stem from different times and places. Six are sutra versions, the seventh is found in the Mūlasarvāstivāda Vinaya. The versions and their abbreviations (in square brackets at the end of each entry) for the following discussion are (arranged by language):

Sutra versions

1. Sutra no. 2 of 34 of the Pali Theravāda Dīgha-nikāya (DN I 47-86) [Pali];

2. Gandhari sutra version of which only the introductory narrative portion survives; the full sutra probably formed a part of the Dirghägama of the Dharmaguptaka community that produced the anthology; the manuscript is dated to the 2nd century CE and originates from the Gandharan region [Gandhari]; ${ }^{37}$

3. Sutra no. 20 of 47 of the Sanskrit Dïrghāgama thought to belong to the Mūlasarvāstivādins; preserved on a manuscript from the Gilgit region dated to the $8-10$ th century CE [Skt. DĀ]; ${ }^{38}$

4. Sutra no. 27 of 30 of the Chinese Dïrghägama, which is generally taken to belong to the Dharmaguptakas; translated in $412-413 \mathrm{CE}$ [Chin. DA $] ;^{39}$

\footnotetext{
37 Manuscript RS 2 in the Robert Senior collection (Allon 2007b). The manuscript is currently being prepared for publication under a Robert H. No Ho Family Foundation Grants for Critical Editions and Scholarly Translations.

38 See Hartmann and Wille (2014). For the carbon dating results, see Allon et al. (2006, p. 279 n. 3 ).

39 T 1 no. 1, pp. 107a20-109c21. For further information, see MacQueen (1988, pp. 16-23), who provides an English translation (pp. 30-50) and Meisig (1987, pp. 13-16).
} 
5. Sutra no. 43.7 of the Chinese Ekottarikāgama, which is sometimes attributed to the Mahāsāmghikas though other schools have been proposed; translated in 384$385 \mathrm{CE}$ and revised 397-398 CE [Chin. EĀ]; ${ }^{40}$

6. Chinese independent translation translated between 381 and $395 \mathrm{CE}$; the school affiliation is uncertain [Chin. IT] ${ }^{41}$

\section{Vinaya version}

7. The Samghabhedavastu of the Mūlasarvāstivāda Vinaya, which is preserved in Sanskrit, Tibetan, and Chinese, contains a non-sutra version. The manuscript of the Sanskrit version dates to the 6th or 7th centuries CE and comes from Gilgit [Skt. SBhV]. ${ }^{42}$

This sutra (and the Vinaya version) depicts king Ajātasattu/Ajātaśatru of Magadha visiting the Buddha and asking him what the fruits are of living life as an ascetic or monk (samanalśramana). Due to the complexity of the material, the multiple sources involved, and the limitation of space, I will concentrate here on the beginning of the narrative. ${ }^{43}$

All versions begin by telling us that the Buddha is staying in Jīvaka's mango/fruit grove in Rājagrha along with 1250 monks. On a full moon night of one or other month associated with the rains (there is variation in which month it is), king Ajâtaśatru is seated in his palace surrounded by his courtiers. The king asks his courtiers and/or ministers what he should do on such a night and/or which ascetic or brahman he should visit who would calm or inspire his mind. Different members of the court recommend various activities. In some versions it is first recommended by different courtiers that he engage in pleasurable activities and engage the military, that is, engage in secular activities. In all versions it is recommended that he visit the six rival teachers of the Buddha's day: Pūraṇa Kassapa/Pūraṇa Kāśyapa, Nigaṇtha Nātaputta/Nirgrantha Jñātiputra, and so on. Here the different versions exhibit variation in the question or questions the king asks, whether only ministers are asked or both courtiers and ministers, whether they are named or not and if named, what name they bear, and what activity or rival teacher each recommends. In the Pali, which is the simplest, the king asks six unnamed ministers which ascetic or brahman he should visit and they each recommend one of the six rival teachers. In Chin. IT the king asks his unnamed ministers how he should dispel his anxiety. The responses of four different ministers are, in turn, through sense pleasures, through listening to music and song, through soldiering, and finally, through visiting the six

\footnotetext{
${ }^{40}$ T 2 no. 125, pp. 762a7-764b12. For details, see MacQueen (1988, pp. 25-26), who provides an English translation (pp. 72-89), and Meisig (1987, pp. 16-19); see also Allon (2001, p. 12) for further references.

41 T 1 no. 22, pp. 270c28-276b6. For further information, see MacQueen (1988, pp. 17, 23-24), who provides an English translation (pp. 51-71) and Meisig (1987, pp. 19-23).

42 The Sanskrit edition is SBhV II 216.8-254.4. Some details of the Chinese version are given by MacQueen (1988, p. 18), who also gives an English translation of it (pp. 90-97).

43 MacQueen (1988) and Meisig (1987) provide detailed accounts of all versions except the new Sanskrit Dïrghāgama (Skt. DĀ) and Gandhari versions, which had not yet been discovered. MacQueen (1988, pp. 30-103) provides English translations of the four Chinese versions. For further discussion, see Allon (2021, pp. 67-73).
} 
teachers. In Chin. EĀ, the king asks eight named courtiers and ministers in turn what he should do on such a night. A named court lady recommends engaging in dance, song, and pleasure. Prince Udāyi recommends military exploits. The remaining named ministers (Prince Abhaya, Minister Sunidha, and so on), each recommend visiting one of the six teachers. In the Skt. SBhV and Skt. DĀ, which both belong to the Mūlasarvāstivāda tradition, the king asks his courtiers what he should do on such a night. In the Skt. SBhV, the first unnamed court lady recommends that they amuse themselves, while in Skt. DA it is that they amuse themselves with music without men in the upper apartment. The second unnamed court lady then recommends amusing themselves and parading around the city wall, though in different order. Prince Udāyibhadra then recommends that they assemble the army and go to war. An old unnamed minister recommends visiting Pūrana Kāśyapa, then an old teacher (Skt. SBhV) or old minister (Skt. DĀ) recommends visiting the remaining five teachers.

The Chin. DA $\bar{A}$ and Gandhari are similar to each other, both probably being associated with the Dharmaguptakas. In both, the king first asks one set of courtiers what he should do on such a night. In Chin. DA $\bar{A}$, an unnamed court lady recommends washing the hair, bathing, and sporting with the women. In the Gandhari she recommends playing music. The Gandhari apparently has a second court lady recommending something, but the manuscript is quite damaged at this point. In the Gandhari, Prince Udāyibhadra then recommends assembling the army and parading around the city wall, while in Chin. DA it is assembling the army, planning an attack, returning, and amusing themselves. A general then recommends military exploits, which differ in the details given. In Chin. DA $\bar{A}$, the king then asks his ministers which ascetic or brahman he should visit on such a night. In both, named ministers, including the king's younger brother Abhaya, recommend visiting the six teachers (or apparently four in the Gandhari, but this appears to be a scribal omission), which show some variation in the order of ministers and who they recommend.

In all but one version, Jivaka, the court physician, who is a follower of the Buddha, is then introduced. In the Pali, Chin. IT, and SBhV-Skt. DA $\bar{A}$ group, the king asks Jīvaka why he is silent. In Chin. EĀ he asks what he should do, while in the Chin. DA and Gandhari he asks what ascetic or brahman he should visit. In all versions, Jīvaka recommends visiting the Buddha. In Chin. E $\bar{A}$ it is stated that the king experienced joy, admits his crime of patricide, and that the king and Jivaka utter some verses. In the Skt. SBhV and Skt. DA it is stated that the king's mind was inclined towards the Buddha.

The relationship between the many versions of this sutra in this narrative introduction is complex with no two versions being identical at every level. This is true even of those that can be attributed to the same school or a closely related school, such as the Sanskrit, Tibetan, and Chinese SBhV versions and the new Sanskrit $\mathrm{DA}$ version.

The above brief comparison of the introductory narrative portion of the surviving versions of the Sämañ̃aphala-sutta/Śrāmanyaphala-sūtra, which only hints at the differences at the level of wording, illustrates well the way in which the account of an event, the plot, was expanded and developed. These developments are certainly 
intentional, the result of creative minds, no doubt motivated by a desire to ever improve the story and make it more compelling. What is particularly interesting about this example is that the most complex and developed plot, that seen in the Gandhari version, is witnessed by the most ancient manuscript by far, namely, by a 2nd century CE Gandhari manuscript (the translation of the parallel Chin. DA version is two centuries later). This illustrates that such changes were happening in the period when oral transmission was still the dominant medium employed by Buddhist communities for the transmission of their texts. It also illustrates that, as seen in many of the examples involving Gandhari versions, that such changes are not the result of Sanskritization, though the process of translating into Sanskrit may well have provided an opportunity to "improve" and polish the text.

It has been argued that changes were most likely to occur in narrative portions of sutras, such as the example just discussed, whereas doctrinal passages and the words spoken by the Buddha were generally more conservative. For example, Anālayo (2011, pp. 886-887) concludes his major study of the sutras of the Majjhima-nikāya and their parallels, by stating "differences between parallel versions tend to affect more often the narrative portions of the text, which are the parts that were more prominently 'commentarial' and thus more directly open to the influence of the reciters. In contrast, what would have been considered by the reciters to be the word of the Buddha appears to have been more resistant to change" and he gives copious references in the accompanying footnotes (p. 887 n. 138 and n. 139) of statements made by others along these lines.

There are certainly many instances where a high degree of stability is witnessed between parallel versions of words spoken by the Buddha, particularly so discreet passages that describe an aspect of the teaching, define a concept and detail a practice. ${ }^{44}$ An example is the second discourse of the Buddha, known in Pali as the Anattalakkhana-sutta, which articulates the not-self nature of the five aggregates. Due to the importance of this topic and the place of the discourse in the life of the Buddha, there are, like the first discourse of the Buddha, numerous versions of it preserved in a variety of languages (Pali, Gandhari, Sanskrit, Tibetan, Chinese) within the Sutta-/Sütra- and Vinaya-pitakas as well as in other texts, that belong to a diversity of schools and originate from different times and places. For a listing of all versions, the reader is referred to Allon (2020), which publishes the Gandhari version. As noted in Allon (2020, p. 214), there is considerable agreement between the surviving versions in the structure and even wording of the text. However, in one section (referred to as section E in Allon, 2020), where the Pali and Gandhari texts are nearly identical, the Sanskrit version is quite different. ${ }^{45}$ I use bold to highlight the differences between those sections that are the same in the three versions and underline to mark the major difference in the Sanskrit.

\footnotetext{
44 For examples, see Allon (2021, pp. 73-76).

45 Pali SN III 68.20-25; Vin I 14.27-32; Gandhari RS 22 no. 2 (11. 24-28); Sanskrit SBhV I 139.10-14, cf. CPS $\S 15.18$ and p. 449. For a more detailed comparison, see Allon (2020).
} 
P evam passam bhikkhave sutavā ariyasāvako rūpasmim pi ${ }^{46}$ nibbindati vedanāya pi nibbindati sañ̃̃āya pi nibbindati sañkhāresu pi nibbindati viñ̃āṇasmim pi nibbindati nibbindam virajjati virāgā vimuccati vimuttasmị̣ vimuttam iti ${ }^{47}$ ñạnam hoti khịnā jāti vusitạn brahmacariyam katam karaṇīyam nāparam itthattāyā ti pajānātī ti.

G e(va paśa śrudava) ariașavao ruehi nividadi vedanae nividad i sañae ṇividadi s(akhare)hi ṇividad $i$ viñaṇaspi nividad $i$. ṇiviṇo virajad $i$ virage vimucadi. vimutaspa vimutam eva ñaṇa bhadi kșina jadi vusida bramahio krida me karanao navaro imadhatva di payanadi. ${ }^{48}$

SBhV yataś ca bhikșavah śrutavān āryaśrāvaka imām pañca upādānaskandhān naivātmato nātmīyatah samanupaśyati sa evam samanupaśyan na kiñcil loka upādatte. anupādadāno na paritasyati aparitasya àtmaiva parinirvāti kṣinnā me jātih uṣitam brahmacaryam krtạn karaṇīyam nāparam asmād bhavam prajānāmìti.

$\mathrm{P}=\mathrm{G}$ Seeing thus, monks, the well-taught, noble disciple is disgusted with forms, disgusted with feeling, disgusted with perception, disgusted with volitional formations, disgusted with consciousness; being disgusted, he is dispassionate; on account of dispassion, [his mind] is liberated; being liberated, there is the knowledge "[my mind] is liberated". He understands, "birth is destroyed, the holy life has been lived, what was to be done has been done, there is no further [being] than this".

SBhV And when, monks, the well-taught noble disciple sees these five aggregates affected by clinging as not-self and as not pertaining to self, (then) seeing thus, he clings to nothing in the world; not clinging, he is not troubled; not troubled, he himself attains Nirvāna. [He understands], "birth for me is destroyed, the holy life has been lived, what was to be done has been done, I know no further being than this".

As discussed in Allon (2020, pp. 218-219), as is typical of this class of literature, the wording of the Sanskrit version that differs (the underlined) is found elsewhere in the Pali canon, while the wording of the Pali and Gandhari is found elsewhere in the canonical literature of the Sarvāstivādins and Mūlasarvāstivādins.

The Mahāparinibbāna-sutta/Mahāparinirvāna-sūtras provide many examples of both impressively stable passages that are presented as reports of what the Buddha said and yet others that exhibit important differences. Worthy of note is an instance where the Sanskrit version appears to have converted what was originally a sutra narrator passage reporting the general topic of the Buddha's discourse into reported speech of the Buddha. This formula - the iti-sīla-samādhi-pañ̃̄a formula in Pali, itiśĭla-samādhi-prajñā formula in Sanskrit-occurs several times throughout these

\footnotetext{
46 The Ee of the Samyutta-nikāya occurrence lacks pi throughout; pi is included in the Ee of the Vinaya occurrence, in the Sinhalese manuscripts used for the Ee of the Samyutta-nikāya, and in the Be, Ce and Se of the both the Samyutta-nikāya and Vinaya occurrences; see Allon (2020, p. 217).

47 So also Be, but Vin Ee vimutt'amhī ti.

48 The reading given here differs slightly from Allon (2020). For the new reading, see https://doi.org/10. 30722/JGBT.2020.001.
} 
Mahāparinibbāna-sutta/Mahāparinirvāṇa-sūtras, though often at different locations:

tatra sudam bhagavā [location: loc.] viharanto [location: loc.] etad eva bahulam bhikkhūnam dhammịn katham karoti: |

iti sīlam iti samādhi iti pañ̃āa | sīlaparibhāvito samādhi mahapphalo hoti mahānisamso. | samādhiparibhāvitā pañ̃̃ā mahapphalā hoti mahānisaṃsā. | pañ̃āaparibhāvitam cittạ̣ sammad eva āsavehi vimuccati | seyyathīdam kāmāsavā bhavāsavā (ditthāasavāa) avijjāsavā ti.

There the Bhagavat, while staying in place $x$, frequently gave a religious talk to the monks: Such is morality, such is concentration, such is understanding. Concentration fortified with morality is of great fruit, of great benefit. Understanding fortified with concentration is of great fruit, of great benefit. The mind fortified with understanding becomes completely released from the taints (äsava), that is, the taint of sense desires, the taint of being, (the taint of views,) the taint of ignorance.
[8.5] tatra bhagavā(n bhikșūn) āmantrayate: | [8.6] itìmāni bhikṣavah sīlāny ayam s(amādhir iyạ̣ prajñā.) | śilaparibhāvitah samādhiś cirasthitiko bhavati. | prajñāparibhāvitam cittam samyag eva vim(u)cyate rägadveșamohebhyah. [8.7] evam samyaksuvimuktacitta āryaśrāvakah samyag (eva) praj(ānāti) kṣīnā me jātir ușitạ̣ brahmacaryạ krtam karaṇ̄yam nāparam asmād bhavạ prajānāmi.

[8.5] There the Bhagavat addressed the monks: [8.6] "Such, monks, are these moralities, this concentration, this understanding. Concentration fortified with morality is long lasting. The mind fortified with understanding becomes completely released from lust, hate, and delusion. [8.7] The noble disciple whose mind is thus completely well-released understands completely: 'Birth for me is destroyed, the holy life has been lived, what was to be done has been done, I know no further being than this.'"

The Pali version of this formula is not found anywhere else in the Pali canon, which suggests that it is the work of those who composed the Mahäparinibbannasutta. The uniqueness of the formula is also witnessed by none of the component elements being found elsewhere in the Pali canon, with the exception of mahapphalā hoti mahānisamsāa. In contrast, virtually all the elements in the Sanskrit version that differ from the Pali version are found elsewhere in the Pali canon, and no doubt in Sanskrit sutra texts also. Given that the Pali formula is unique to the Mahāparinibbāna-sutta, while the wording of the latter half of the Sanskrit version, which is the section that most differs from the Pali, consists of wording found in other sutras, it would appear that the differences between the two versions are due to modifications undertaken by those who transmitted the Sanskrit version or a Prakrit predecessor to it. This is also supported by the lack of symmetry in the Sanskrit version, which the Pali version certainly has with its threefold structuring, the omission of the equivalent of the samādhiparibhāvitā phrase contributing to the lack of symmetry in the Sanskrit. Interestingly, the Sanskrit takes these words to be those of the Buddha, introducing them with tatra bhagavān bhikșūn ämantrayate, "there the Bhagavat addressed the monks", and including the vocative bhikșavah, "monks", in the formula itself, where such a vocative of address only occurs in reported speech. In contrast, in the Pali the passage is introduced with the words tatra sudam bhagavā [location: loc.] viharanto [location: loc.] etad eva bahulam bhikkhūnam dhammim katham karoti, "there the Bhagavat, while staying in

$\overline{49}$ See Anālayo (2011, p. 382 esp. n. 217) 
place $x$, frequently gave a religious talk to the monks", with the following wording lacking the vocative, which indicate that these are the words of the sutra narrator summarizing the general topic of the Buddha's discourse. By including wording spoken by the Buddha found in other sutras in this passage, those responsible for the Sanskrit version converted what was originally a sutra narrator statement into the words of the Buddha.

As is well known, the Pātimokkha-sutta/Prätimokșa-sūtra rules are held by all Buddhist communities to have been formulated by the Buddha himself and were recited by each community every fortnight at the formal uposatha (poșathal poșadhalupoșadha) ceremony. Because of the importance of the Pātimokkhal Prātimokșa and the survival of so many Vinayas, we have the Pātimokkhal Prätimokșa rules for the monks, in full or in part, belonging to at least nine schools preserved in a variety of languages and witnessed in a variety of manuscripts and dated translations stemming from different times and locations. Its importance in the current study is that the Pātimokkha/Prâtimokșa is universally accepted in traditional sources and in modern scholarship as having been a fixed, memorized text that was regularly recited; and that although it may not have always been recited communally in the sense that all monastics recited it together, it was recited in a communal setting with all monastics expected to know and understand it. Yet a comparison of the surviving Pātimokkha/Prätimokșa rules reveals important differences, as a detailed study of the four surviving Indic versions of the second Sañghādisesa/Samghātiśeșa/Samghāvaśeșa rule illustrates (Allon, 2021, pp. 86-93).

Anālayo (2014a, pp. 53-54; 2020a, pp. 2719-2720; 2020b, pp. 396-402) draws attention to the differences between the Pātimokkha/Prātimokșas but considers that they are due to errors of memory, monastics knowing the meaning of the text, the intrusion of commentarial material into the root text, and other unintentional factors as he does generally for differences between sutras. ${ }^{50} \mathrm{He}$ also argues against any possibility of the Pātimokkha/Prātimokșa being intentionally changed because of its importance to the community and its function in defining the community's identity. Indeed, some of the differences in the versions of the Sanghädisesa rule discussed in Allon, (2021, pp. 86-93) do appear to have their origins in commentarial material, but I would argue that most of them have resulted from active desire to clarify and to smooth awkward formulations, drawing heavily on the authoritative commentarial tradition to do so, a process that is also evident in sutra texts. Also, given that the Pātimokkha/Prātimokșa was recited so frequently, and always by a group or in a group setting, with all monastics supposedly knowing it, any accidental change, error, or divergence from the memorized version would have been corrected. Even in a situation where the monastic community was inclined to follow the highly revered senior monk's altered recitation of the monastic rules out of respect and inability to challenge the alteration, there must have been an awareness by the community of the difference and tacit agreement on their part to adopt the modified version. It is also hard to believe that the lead reciter, who performed the recitation of the Pātimokkha/Prätimokșa precisely because of his command of it, would not at some point have become aware that his recitation differed from his previous one, for

$\overline{50}$ For sutras, see Anālayo (2011 pp. 855-891; cf. 2009, 2014a, 2015, pp. 89-91). 
example, when another monk led the recitation using the original wording or a senior monk from a neighbouring monastery of the same nikāya attended the recitation. Further, although the Pātimokkha/Prätimokșa did play such an important role in the monastic community, which resulted in a conservative attitude being held towards it, the changes encountered generally do not alter the meaning of the rules. Rather, these changes are attempts to make the meaning of the rule clearer and therefore less likely to be misunderstood, which was the motive for the production of the accompanying introductory stories (vatthu) and the word for word explanations (padabhäjanīya) on the rules, the changes thus being in keeping with the function of the Pâtimokkha/Prātimokșa. Finally, there are many examples of manuscripts that preserve remnants of the Prātimokșa that diverge from the standard version transmitted by the community that most likely produced the manuscript, though the phenomenon has yet to be fully explained. ${ }^{51}$

By way of summary, although there are many examples of passages that record the words of the Buddha exhibiting minimal differences among surviving versions, this is by no means the rule.

In the Pali canon we sometimes find differences in the account of the same event recorded in different sections of the canon. ${ }^{52}$ These differences are most likely due either to differences in the function and use of each of these collections or to the tradition of bhānaka reciters or a combination of these two. These differences show that ideally when comparing parallel versions of texts belonging to different schools that are witnessed in manuscripts or translations that differ in date and place of origin, we should take into consideration the contextual information of each witness: the function of the text and the collection it belongs to, why it was produced, who was the intended audience, why the manuscript or manuscripts that witnesses the text was produced, how and by whom the text was transmitted, and so on. Clearly, these factors affected many aspects of a text: its size, the nature and complexity of the descriptions it contained, the inclusion or omission of passages, the way in which ideas are developed and teachings and practices presented, and so on. And in the case of manuscripts, a sutra written for interment in a stupa as a religious act, one written for didactic purposes, one written for one's personal use, and the one recited communally may very well not be identical.

Differences between different schools or textual communities in the ordering of sutras and verses within a collection and differences in the allocation of a sutra or verse to a particular collection or section within a collection is one of the most dominant and defining characteristics of canonical collections and texts and does not require further discussion, having been documented by several scholars. ${ }^{53}$ In the vast majority of cases, such reordering and rearranging of textual units must have been intentional. Further, the implementation of such largescale editorial projects must have involved quite some effort in terms of decision making, eliciting consensus and adapting to the change. Although learning a new order of familiar sutras may not have been that difficult, the movement of sutras between nikāyas/

\footnotetext{
51 See Allon (2021, p. 93 n. 185), for details.

52 See Allon (2021, pp. 99-102), for examples and discussion.

53 See Allon (2021, pp. 105-108), for further discussion.
} 
ägamas would have required the reciters of that nikāyalāgama to learn the new sutras, though they may well have already have been familiar with them.

But undoubtedly the most significant and grossest form of intentional change that reciters had to deal with would have been learning completely new sutras that had been created or adopted by the community and included in one or other agamal nikāya, a phenomenon for which there is substantial evidence. ${ }^{54}$ Although we cannot be certain that the sutras that lack a parallel in the canonical collections belonging to other schools available to us are late additions, there are enough instances of them to show that communities continued to create sutras for some time after textual lineages became separated, which of course is just a continuation of a process that began at the time of Buddha or shortly thereafter. Of all forms of change, the learning of a new sutra probably entailed the greatest amount of effort.

\section{Recent Scholarship on the Composition of Early Buddhist Texts, and Initiating and Adapting to Change}

Despite early Buddhist sutra texts being designed to facilitate their memorization and oral transmission, as witnessed by their stylistic features and their organization within collections, and despite the deeply rooted institution of memorizing texts and reciting them communally that required the text be fixed, these texts underwent many changes throughout the long history of their transmission, both intentionally and unintentionally produced. Now change, and most importantly, intentional change, surely posed major problems to the oral transmission of fixed texts, particularly when undertaken through communal recitation. How did reciter communities who had invested a huge amount of time and effort into memorizing texts adapt to the changes made to the texts of the kind outlined in this study? How were the changes and innovations accepted? By group consensus or by a top-down model with senior monastics or recitation masters authorizing the adoption of the innovations, or both? How were such changes implemented? Did the recitation master(s) lead the community of reciters in learning the new version? And were such changes generally the result of considered pre-recitation, pre-performance, creative impulses or did they also have their origin in innovations produced in the course of someone giving a sermon based on the memorized text?

Before pursuing these questions, I would like to first respond to several recent publications that address the issue of the composition of early Buddhist texts. The first is Nathan McGovern's (2019), "Protestant Presuppositions and the Study of the Early Buddhist Oral Tradition". In his paper, which nuances ideas proposed by Lance Cousins (1983), McGovern argues against the idea that early Buddhist texts were designed as fixed texts to be transmitted verbatim as proposed by, for example, Bhikkhu Anālayo, Richard Gombrich, Alexander Wynne, and myself, considering rather that they were in fact created in performance using fixed or relatively fixed formulas and narrative frames within an improvisatory but conservative oral tradition, the basic stable textual unit being the formula rather than the sutra.

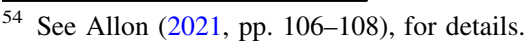


Regarding improvisation, he states, “'Improvisation' simply means that the text as a whole was not memorized word-for-word, and that a roughly similar, but not exactly identical text could be reproduced with each performance through the use of formulas" (p. 461, italics original). And he argues that this better explains the differences we see between parallel versions of sutras: "What we are clearly seeing in the different versions of the early Buddhist sütras is snapshots of performances of what was once a living oral tradition. In this oral tradition, stock formulas and narrative frameworks maintained a remarkable consistency (especially in doctrine) over the centuries, but each performance was nevertheless made without resort to a fixed, memorized text" (p. 484). He maintains that "deliberate memorization is not supported by the evidence" (p. 451), there being "absolutely no basis for the assumption that early Buddhist discourse (sütrāntas) in their entirety could only be faithfully preserved and transmitted through strict memorization" (p. 487).

First, as briefly outlined here and as illustrated in more detail in Allon (2021), the evidence in fact shows that Buddhist communities composed and memorized fixed text from a very early period, if not within the Buddha's lifetime, but that most communities, if not all, were willing to change the wording, structure, complexity, and so on, of the texts they transmitted to better suit their purposes. The examples of texts we have belonging to different communities transmitted at different times and places are not the frozen snapshots of oral performances, but formal "editions" sanctioned by the community concerned. It may well have been the case that innovations that occurred in the course of a skilled monastic delivering a sermon in public or within a monastic setting on what the Buddha and others did and said or on a particular aspect of the Dharma, which drew on the memorized text and involved quoting passages from it, were introduced into the memorized text because they were felt to be improvements, but these sermons were very different from the fixed, memorized texts transmitted by the community.

Further, why innovate and improvise in public performance with such a high degree of internal repetition that we encounter in these texts? Why not just report what happened and what the Buddha said in normal speech as a preacher would? The Buddha would not have spoken in the way he is depicted as speaking in these texts, though given the oral context his sermons may have appeared peculiar to the modern ear, and one could not imagine that a latter-day preacher would deliver a sermon with all the features of the sutras that we have, which I think only make sense in the context of the oral transmission of fixed text.

Again, McGovern (pp. 462-463) critiques three of the examples Wynne (2004) presents as evidence of word-for-word memorization, the first two of which concerns the Pátimokkha. In his counter to the first of those concerning the Pātimokkha, McGovern (p. 463) states that "No one would seriously doubt that this list of rules was memorized". But as I have noted, despite being a fixed, memorized text that was recited communally, or in a communal setting, they were willing to change the wording of them. Further, the types of differences we see between the Pātimokkha/Prātimokșas belonging to different communities are very similar to the types of differences we see between parallel versions of sutras, though less pronounced due no doubt to the more conservative attitude towards the Pätimokkhal Prātimokșa and because of the frequency of recital. If the differences between the 
Pātimokkha/Prätimokșas, which were fixed, memorized texts, can be accounted for through intentional change, then so can the differences between parallel versions of sutras, once we have accounted for those that arose through unintentional means. And here intentional change is not improvisation, but conscious change to text that is being transmitted as a fixed text.

Regarding McGovern's understanding of formulas being the fixed, memorized units rather than the sutra as a whole, formulas themselves are no more conservative than the sutras. As we have seen, although expressing the same idea, the same formulas found in texts belonging to different traditions and preserved in different Indic languages are rarely identical. We have also seen that even in Pali suttas there is some variation in formulas used to depict the same event or idea, particularly between different sections of the canon. Again, to make the formula the base fixed, memorized unit, would mean that the focus of the reciters' attention was primarily on memorizing these formula-units, yet we have no evidence of this, no handbook of formulas, no mention of monks learning formulas. Similarly, how were the narrative frames or outlines of the sutras learnt? It is hard to imagine that the focus was on learning a body of formulas and narrative frames, not actual sutras. To understand how formulas work and are used, one would have to learn them in their context. I think a more likely scenario for preachers is that, on the basis of having learnt a corpus of memorized texts, he or she would give a free-flowing natural sermon punctuated by the quoting of passages from the memorized sutras and verse collections accompanied by commentary on and analysis of the quoted passage. Alongside this, monastics would have given public recitations of the fixed, memorized text, much as is done in Buddhist communities today. To my mind, both the similarities and differences we encounter between versions of sutras as discussed in the current work show that a memorized text lay behind them and that those who transmitted these texts consciously reworked them to improve them, to make them more compelling, to make them better suit their purposes and their understanding of their audience's expectations, to make them better reflect their understanding of the Buddha and his teaching, sometimes also creating new sutras on the basis of familiar elements.

Again, in Allon (1997b), I argued that the Buddhist community and its reasons for composing and transmitting texts were on virtually all counts so very different to those who performed oral epics for which oral theory as outlined by McGovern was formulated. It is also the case that Buddhists had as their model the Brahmanical tradition of transmitting fixed texts, not the bardic tradition that initially produced the Indian oral epics such as the Mahäbhärata and Rāmāyaña.

Finally, had improvisation been the norm, even if textual communities were on the whole conservative, we would surely see far greater differences than we do see.

The other recent publications that address the issue of the composition of early Buddhist texts are Eviatar Shulman's articles "Looking for Samatha and Vipassanā in the Early Suttas: What, actually, are the Texts?" (2019) and "Orality and Creativity in Early Buddhist Discourses" (2021a), and his book Visions of the Buddha: Creative Dimensions of Early Buddhist Scripture (Oxford University Press, 2021b). Unlike McGovern, Shulman does not doubt that the memorization of texts was integral to the transmission of texts by Buddhist communities (e.g. 2021a) and 
he does not subscribe to the Parry-Lord model of improvisation as it stands. Shulman then goes on to describe some of the ways in which new texts may have been composed by means of formulas, by the "play of formulas" as he calls it, that were already in use by the community, adapted them to suit the context, or creating new ones for that context if one was not readily available, the community then adopting that text if it was felt to be compelling enough. However, like McGovern, Shulman takes formulas as the primary textual elements, though his understanding of formulas is certainly not the same as McGovern's. For example, he states

The main building blocks of Buddhist discourse were formulas, which reciters knew by heart. This does not mean, however, that the bearers of the tradition merely repeated what they previously heard and recited. They rather used these formulas in order to create new articulations of Buddhist vision, which in many ways repeated what they had previously heard but were nonetheless new. These articulations were both traditional, conservative expressions and new, creative material. When a new text was introduced it looked much like the texts everybody knew by heart, and therefore could be "brought into sutta" in light of its specific "words and letters." (2021a, pp. 223-224)

further

Formulas are the texts, and any new element that is introduced must become a formula and fit the requirements of genre. Formulas are primary to texts, and they are accepted building blocks from which one can produce a possibly infinite array of legitimate Buddhist scriptures. So long as texts are founded on accepted formulas, they have every chance of being recognized as "true" Buddhist speech. (2021a, p. 229; italics original)

and

These scholarly works, together with Allon's [1997b] central study of early Buddhist orality and other major studies of the nature of the early suttas, share two foundational, unquestioned assumptions. The first is that the basic analytical category for the study of early Buddhist textuality is the discourse, as we find it today in Buddhist canons or collections in different languages, which were set for transmission. In response, I argue that formulas are the fundamental textual element, and discourses are products of formulas, not only in the sense that they are composed of formulas, but also in that a basic practice of early Buddhist textuality was combining formulas in different ways to produce ever more Buddhist discourses. ${ }^{55}$

Although new texts were undoubtedly created using pre-existing formulas, that does not make formulas the primary textual element. The creation of a text requires a plot, an idea, a structure, a purpose and motivation. Formulas are the means by which plot, idea, structure, and purpose are realized in concrete form. Both categories of literary feature are essential to the composition of a text.

$\overline{55}$ Shulman 2021b, Conclusion to Chapter 1. 
Shulman (2021a, p. 193) also takes issue with formulas being seen primarily as aids to the memorizing of text (referring to Allon, 1997b, among others), arguing that they are much more than this, in particular, "their poetic and aesthetic aspects are among their primary features, not only from a literary perspective but even from a religious or philosophical one" and that "[t]hey are first and foremost designed to create a particular, compelling perception of the Buddha and of his message". But this is to confuse the wording of the formula with the formula status of that wording. It is certainly the case that the wording that constitutes some formulas has poetic and aesthetic aspects, etc. However, that wording becomes a formula and is recognized as a formula through its repetitive use, though it may be modified to suit the context following predictable patterns. In the case of early Buddhist prose texts, the structural features of the formula and the Lego-like building blocks of which it is constructed may also contribute to its recognizability as a formula. The fabric of the text, the wording, is, as we have seen, so highly structured and carefully crafted that even where a phrase or passage is not encountered elsewhere in the corpus of sutras transmitted by the community concerned, it is in effect a formula by its potential to be used and reused to depict the same idea in another text. Canonical prose is in effect constituted by formulas. The question is, why choose highly structured and standardized, that is, formulaic, wording to give a compelling perception of the Buddha and his message? Or more broadly, why use the same wording time and again to depict a given quality, attainment, practice, thought, concept, action, event, or the like? Why not use innovative and poetically rich wording that differed on each telling, each text, each description being unique, the diversity and richness adding to the appeal of the text and the perception of the Buddha and his teaching? As I argued in Allon (1997b), the primary function of formulas in early Buddhist prose sutra texts is to aid composition and transmission of fixed texts, though I tended to concentrate in that study on the latter mnemonic function. But formulaic diction, as distinct from the wording and its meaning that constitutes the formulas, certainly had other functions. Examples are imparting solemnity, gravitas, and authority to the material, that is, making it suitably "religious", thereby inducing respect and reverence; relaying legitimacy; producing predictability, which combined with other forms of repetition enabled the audience to grasp and remember what was said and to participate in the recital (at least mentally), much as one might sing along when hearing one's favourite song; and inducing certain states of mind, moods and emotional responses.

Finally, Shulman is certainly correct to argue that the preservation of the Buddha's teaching was not the only function of early Buddhist texts and to emphasise the literary and creative dimensions of this literature. So also, he is correct in arguing that texts were not necessarily composed to report historical events.

Coming back to the initial question of how reciter communities changed the texts they transmitted and adapted to it, like much concerning the early history of Buddhist communities, we can, unfortunately, only really guess at the processes involved. Presumably, given that seniority in ordination along with skill and accomplishment determined hierarchy in the Buddhist monastic community, the introduction of intentional change or the formal adoption of what had originally 
been unintentional changes would have been a top-down affair with consensus of the community at large not being required for a new version to be authorized as the version to be memorized and recited. Senior reciters would have led the way by memorizing the new version and leading junior reciters in the new recitation following the method used for memorizing communal texts generally. In the case of adapting to change, although there are many differences between parallel versions of early Buddhist sutras, the degree of similarity indicates that Buddhist communities were on the whole quite conservative regarding the texts they transmitted, which means that reciter communities probably did not have to face this problem that frequently. With so little evidence available to us, it is currently impossible to accurately determine when and where a particular change or set of changes first took place.

It is also the case that many of the changes discussed in this study appeared to have been introduced gradually. This is particularly evident when we line up the Pali, Gandhari and Sanskrit versions, where the Gandhari versions often witness some of the changes seen in the Sanskrit versions but not all of them, or not to the same degree. ${ }^{56}$ The implication is that reciters had to adapt to change only gradually.

Finally, the impact of change when it was introduced would have only been experienced by one generation of reciters, that is, by the monastics who knew the pre-change version and had to learn the new version. Since at this stage they had well-developed faculties for memorization and recitation and had at their disposal a large body of textual material and its components, this may not have been such a difficult thing for these advanced reciters to have done. And all subsequent generations and all those who did not know the pre-change version were in the same position as any beginner faced with the task of memorizing a text or collection of texts, which of course, was no minor undertaking.

Acknowledgments This article condenses ideas presented in my recent book The Composition and Transmission of Early Buddhist Texts with Specific Reference to Sutras (Allon 2021), which in turn is based on a paper "The composition and transmission of early Buddhist texts with specific reference to sutras" I delivered at the conference The Idea of Text in Buddhism, Hebrew University of Jerusalem, 10 -12 December 2019. I would like to thank Eviatar Shulman for inviting me to the conference and the Khyentse Foundation for funding it. I gained much from the stimulating conversations I had with Eviatar during my stay in Jerusalem and from comments on my paper from participants. I would also like to thank those who provided information relevant to this study and research materials difficult to obtain during this COVID-19 isolation period, including Bhikkhu Anālayo, Chiew Hui Ho, Aruna Gamage, Jens-Uwe Hartmann, Oskar von Hinüber, Petra Kieffer-Pülz, Jim Rheingans, Andrea Schlosser, Richard Salomon, Ingo Strauch, and Klaus Wille.

Author contributions Full authorship by MA.

Funding Not applicable.

Availability of data and material Not applicable.

56 Allon (2001, pp. 36-37). 
Code availability Not applicable.

\section{Declarations}

Conflict of interest Not applicable.

\section{Abbreviations}

For complete citations to text editions, see References. For Pali texts, see Bechert (1990).

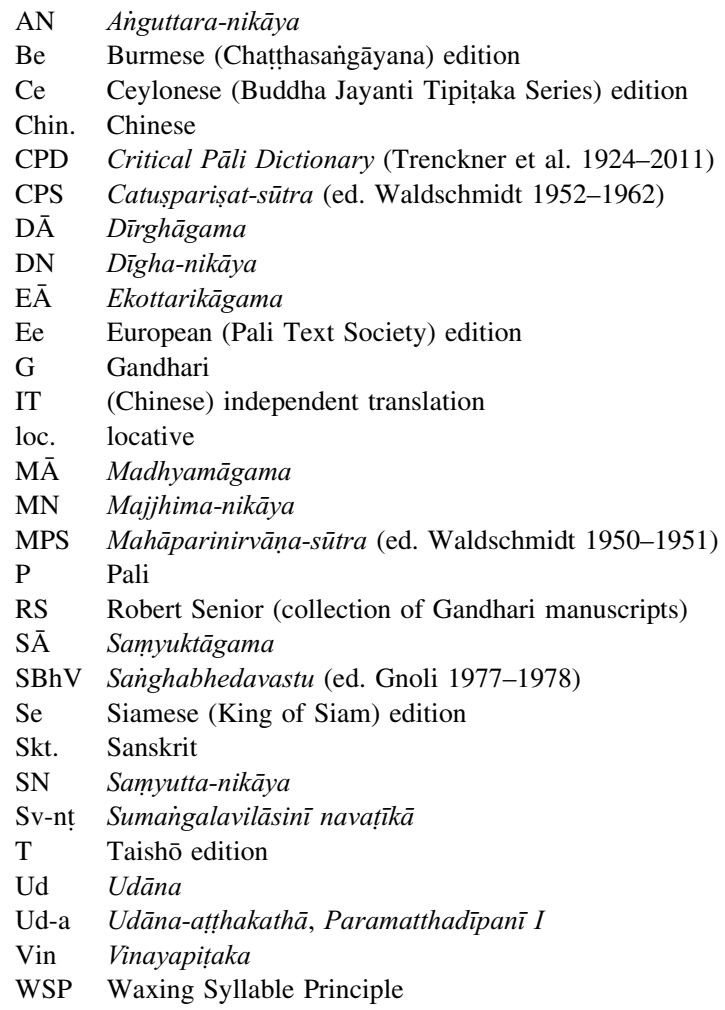

\section{References}

Allon, M. (1987). The Mahāparinirvāna-sūtra (incorporating the Mahāsudarśana-sūtra) being the "Sanskrit" Version of the Pali Mahāparinibbāna-sutta and the Mahāsudassana-sutta (a translation with explanatory footnotes edited in comparison with the corresponding Pali with an introductory essay and a supplementary word index). Honours sub-thesis, South and West Asia Centre, Faculty of Asian Studies, Australian National University. 
Allon, M. (1997a). The oral composition and transmission of early buddhist texts. In P. Connolly and S. Hamilton (Eds.), Indian insights: Buddhism, Brahmanism and Bhakti. Papers from the annual spalding symposium on Indian religion, (pp. 39-61). Luzac Oriental.

Allon, M. (1997b). Style and function: A study of the dominant stylistic features of the prose portions of Pāli canonical sutta texts and their mnemonic function. Studia Philologica Buddhica Monograph Series 12. International Institute for Buddhist Studies.

Allon, M. (2001). Three Gāndhārī Ekottarikāgama $\square$ Type Sūtras: British library Kharoșthī fragments 12 and 14. Gandhāran Buddhist Texts 2. University of Washington Press.

Allon, M. (2007a). A Gāndhārī version of the simile of the turtle and the hole in the yoke. Journal of the Pali Text Society, 29, 229-262.

Allon, M. (2007b). Introduction: The senior manuscripts. In A. Glass (Ed.), Four Gāndhārī Samyuktāgama Sūtras: Senior Kharoșthī Fragment 5. Gandhāran Buddhist Texts 4 (pp. 3-25). University of Washington Press.

Allon, M. (2009[2013]). A Gāndhārī version of the story of the merchants Tapussa and Bhallika. Bulletin of the Asia Institute, 23, 9-19.

Allon, M. (2018). The formation of canons in the early Indian nikāyas or schools in the light of the new Gāndhārī manuscript finds. Buddhist Studies Review, 35, 225-244.

Allon, M. (2020). A Gandhari Samyukta-āgama Version of the 'Discourse on Not-self' (P Anattalakkhaṇa-sutta, Skt. *Anātmalakșaṇa-sūtra). In Dhammadinnā (Ed.), Research on the Samyukta-āgama. Dharma Drum Institute of Liberal Arts Research Series 8 (pp. 201-258). Dharma Drum Publishing Co.

Allon, M. (2021). The composition and transmission of early Buddhist texts with specific reference to sutras. Hamburg Buddhist Studies Series Hamburg Buddhist Studies 17. Projekt Verlag.

Allon, M., \& Salomon, R. (2000). Kharoșthī fragments of a Gāndhārī version of the Mahāparinirvāṇasūtra. In J. Braarvig (Ed.), Buddhist manuscripts, volume I. Manuscripts in the Schøyen collection I (pp. 243-273). Hermes Academic Publishing.

Allon, M., Salomon, R., Jacobsen, G., \& Zoppi, U. (2006). Radiocarbon dating of Kharoșthī fragments from the Schøyen and senior manuscript collections. In J. Braarvig (Ed.), Buddhist Manuscripts III. Manuscripts in the Schøyen Collection 4 (pp. 279-291). Hermes Publishing.

Anālayo, B. (2009). The vicissitudes of memory and early buddhist oral transmission. Canadian Journal of Buddhist Studies, 5, 5-19.

Anālayo, B. (2011). A comparative study of the Majjhima-nikāya. 2 vols. Dharma Drum Publishing.

Anālayo, B. (2014a). The Brahmajāla and the early Buddhist oral tradition. Annual Report of the International Research Institute for Advanced Buddhology at Soka University for the Academic Year 2013 (ARIRIAB), 17, 41-59.

Anālayo, B. (2014b). The Buddha's last meditation in the Dìrgha-āgama. Indian International Journal of Buddhist Studies, 15, 1-43.

Anālayo, B. (2015). The Brahmajāla and the early Buddhist oral tradition (2). Annual Report of the International Research Institute for Advanced Buddhology at Soka University for the Academic Year 2014 (ARIRIAB), 18, 79-94.

Anālayo, B. (2020a). Early buddhist oral transmission and the problem of accurate source monitoring. Mindfulness, 11, 2715-2724.

Anālayo, B. (2020b). 'Mūlasarvāstivādin and Sarvāstivādin': Oral transmission lineages of Āgama texts. In Dhammadinnā (Ed.), Research on the Samyukta-āgama. Dharma Drum Institute of Liberal Arts Research Series 8 (pp. 388-426). Dharma Drum Publishing Co.

Bechert, H. (1988). 'Alte Veḍhas' im Pāli-Kanon. Die metrische Struktur der buddhistischen Bekenntnisformel. Nachrichten der Akademie der Wissenschaften in Göttingen, I. Philologisch-Historische Klasse, 1988, 4 (pp. 119-132). Vandenhoeck and Ruprecht.

Bechert, H. (1990). Abkürzungsverzeichnis zur buddhistischen Literatur in Indien und Südostasien. Sanskrit-Wörterbuch der buddhistischen Texte aus den Turfan-Funden, Beiheft 3. Vandenhoeck and Ruprecht.

Bechert, H. (1991). A Metric 'varṇaka' in the Pāli Scriptures. In The editorial committee of the felicitation volume of professor Dr. Egaku Mayeda (Eds.), Studies in Buddhism and culture in honour of Professor E. Mayeda on his 65th Birthday (pp. 23-30). Sankibo Busshorin.

Collins, S. (1992). Notes on some oral aspects of Pali literature. Indo-Iranian Journal, 35, 121-135.

Cousins, L. (1983). Pali oral literature. In P. Denwood, \& A. Piatigorsky (Eds.), Buddhist studies ancient and modern. Collected papers on South Asia 4 (pp. 1-11). Curzon Press.

Drewes, D. (2015). Oral texts in Indian Mahāyāna. Indo-Iranian Journal, 58(2), 117-141. 
Gamage, A. K. (2012). Some facets of the Theravāda oral tradition. Sri Lanka International Journal of Buddhist Studies, 2, 134-150.

Gethin, R. (2007). What's in a repetition? On counting the suttas in the Samyutta-nikāya. Journal of the Pali Text Society, 29, 365-387.

Hartmann, J.-U., \& Wille, K. (2014). The Manuscript of the Dìrghāgama and the private collection in virginia. In P. Harrison \& J. -U. Hartmann (Eds.), From birch bark to digital data: Recent advances in Buddhist manuscript research. Papers presented at the Conference Indic Buddhist manuscripts: The state of the field Stanford, June 15-19 2009. Österreichische Akademie der Wissenschaften, philosophisch-historische Klasse, Denkschriften, 460. Band / Beiträge zur Kultur- und Geistesgeschichte Asiens, Nr. 80. Verlag der Österreichischen Akademie der Wissenschaften.

Kuan, T.-F., \& Bucknell, R. (2019). The structure and formation of the Anguttara Nikāya and the Ekottarika Āgama. Buddhist Studies Review, 36(2), 141-166.

Lamotte, É. (1985). The assessment of the textual interpretation in Buddhism. tr. Sara Boin-Webb. Buddhist Studies Review, (2), 4-24. [Reprint in D. S. Lopez Jr. (Ed.). 1988. Buddhist Hermeneutics (pp. 11-27). University of Hawaii Press.]

MacQueen, G. (1988). A study of the Śrāmanyaphala-sūtra. Freiburger Beiträge zur Indologie 21. Otto Harrassowitz.

McGovern, N. (2019). Protestant presuppositions and the study of the early buddhist oral tradition. Journal of the International Association of Buddhist Studies, 42, 449-491.

Meisig, K. (1987). Das Śrāmanyaphala-sūtra, Synoptische Übersetzung und Glossar der chinesischen Fassungen verglichen mit dem Sanskrit und Pāli. Freiburger Beiträge zur Indologie 19. Otto Harrassowitz.

Norman, K. R. (2006). 2nd ed. A philological approach to Buddhism: The Bukkyō Dendō Kyōkai lectures 1994. The Pali Text Society.

Shulman, E. (2012[2013]). Early buddhist imagination: The Atthakavagga as Buddhist poetry. Journal of the International Association of Buddhist Studies, 35(1-2), 363-411.

Shulman, E. (2017). The early discourses of the Buddha as literature: Narrative features of the Digha Nikāya. The Journal of Religion, 97(3), 360-387.

Shulman, E. (2019). Looking for Samatha and Vipassanā in the early suttas: What, actually, are the texts? Indian International Journal of Buddhist Studies, 20, 95-141.

Shulman, E. (2021a). Orality and creativity in early Buddhist discourses. In L. O. Gómez, \& N. Gummer (Eds.), The Language of the Sütras (pp. 187-230). Mangalam Research Institute.

Shulman, E. (2021b). Visions of the Buddha: Creative dimensions of early Buddhist scripture. Oxford University Press.

von Hinüber, O. (1994). Untersuchungen zur Mündlichkeit früher mittelindischer Texte der Buddhisten. Untersuchungen zur Sprachgeschichte und Handschriftenkunde des Pali III. Akademie der Wissenschaften und der Literatur, Mainz. Abhandlungen der geistes- und sozialwissenschaftlichen Klasse, Jg 1994, Nr. 5. (Untersuchungen zur Sprachgeschichte und Handschriftenkunde des Pali III). Franz Steiner Verlag.

von Hinüber, O. (2019). The Buddha as a historical person. Journal of the International Association of Buddhist Studies, 42, 231-264.

von Simson, G. (1965). Zur Diktion einiger Lehrtexte des buddhistischen Sanskritkanons. J. Kitzinger.

Trenckner, V. et al. (1924-2001). A critical Pāli dictionary. 3 vols. Copenhagen: The Royal Danish Academy of Sciences and Letters/The Department of Asian Studies, University of Copenhagen.

Waldschmidt, E. (1939). Beiträge zur Textgeschichte des Mahāparinirvānasūutra. Nachrichten von der Gesellschaft der Wissenschaften zu Göttingen. Philologisch-historische Klasse. Fachgruppe III. Allgemeine Sprachwissenschaft. Östliche Kulturkreise. Neue Folge, Bd. II, Nr. 3. Vandenhoeck \& Ruprecht. [Reprint Von Ceylon bis Turfan: Schriften zur Geschichte, Literatur, Religion und Kunst des indischen Kulturraumes. Festgabe zum 70. Geburtstag, am 15. Juli 1967 (pp. 80-94). Vandenhoeck \& Ruprecht.]

Waldschmidt, E. (1950-1951). Das Mahāparinirvānasūtra: Text in Sanskrit und Tibetisch, verglichen mit dem Pāli nebst einer Übersetzung der chinesischen Entsprechung im Vinaya der Mūlasarvāstivādins. 3 vols. Abhandlungen der Deutschen Akademie der Wissenschaften zu Berlin, Klasse für Sprachen, Literatur und Kunst, 1949, no. 1, 1950, nos. 2-3. Akademie-Verlag. 
Weber, C. (1999). Buddhistische Sutras: das Leben des Buddha in Quellentexten. Heinrich Hugendubel Verlag.

Wynne, A. (2004). The oral transmission of early Buddhist literature. Journal of the International Association of Buddhist Studies, 27(1), 97-127.

Publisher's Note Springer Nature remains neutral with regard to jurisdictional claims in published maps and institutional affiliations. 